\title{
Miskonsepsi BuKu AJAR Fisika SMA Kelas X PAda POKOK BAhasan DINAMIKA GERAK
}

\author{
Fachmi Nurdiansyah $^{1)}$, Andika Kusuma Wijaya ${ }^{2)}$, Eka Murdani ${ }^{3)}$ \\ 1) Program Studi Pendidikan Fisika, STKIP Singkawang \\ E-mail: nurdiansyah_fachmi@yahoo.co.id \\ 2) Program Studi Pendidikan Fisika, STKIP Singkawang \\ E-mail: andikakusumawijaya1988@gmail.com \\ 2) Program Studi Pendidikan Fisika, STKIP Singkawang \\ E-mail: ekamurdani@gmail.com
}

\begin{abstract}
Abstrak. Penelitian ini bertujuan untuk memaparkan bentuk-bentuk miskonsepsi pada pokok bahasan dinamika gerak dalam buku ajar fisika SMA kelas X. Adapun buku ajar yang digunakan dalam penelitian ini, yaitu: (1) Fisika untuk SMA/MA Kelas X Semester I karangan RA dan SI yang diterbitkan tahun 2012 oleh penerbit IP, (2) Fisika untuk SMA/MA Kelas X Semester I karangan TPM yang diterbitkan tahun 2013 oleh penerbit VP, dan (3) Fisika Peminatan untuk SMA/MA Kelas X karangan SN dan SZ yang diterbitkan tahun 2013 oleh penerbit YW. Penelitian ini merupakan penelitian kualitatif deskriptif. Objek dalam penelitian ini adalah data berupa aspek penjelasan konsep, penulisan rumus, penulisan simbol, penulisan satuan, dan penyajian gambar pada pokok bahasan dinamika gerak dalam buku ajar fisika SMA. Penelitian dilakukan dengan cara menganalisis data dalam buku ajar fisika SMA yang dibandingkan dengan buku teks fisika universitas. Berdasarkan analisis data yang telah dilakukan, dapat disimpulkan bahwa miskonsepsi pada pokok bahasan dinamika gerak terdapat dalam buku ajar fisika SMA. Buku ajar IP mengalami miskonsepsi pada aspek penjelasan konsep dengan persentase $10 \%$, penulisan rumus dengan persentase $57,14 \%$, penulisan simbol dengan persentase $46,15 \%$, dan penyajian gambar dengan persentase 20\%. Buku ajar VP mengalami miskonsepsi pada aspek penjelasan konsep dengan persentase $10 \%$, penulisan rumus dengan persentase $85,71 \%$, penulisan simbol dengan persentase $79,62 \%$, dan penyajian gambar dengan persentase $80 \%$. Buku ajar YW mengalami miskonsepsi pada aspek penjelasan konsep dengan persentase $10 \%$, penulisan rumus dengan persentase $85,71 \%$, penulisan simbol dengan persentase 69,23 , dan penyajian gambar dengan persentase $20 \%$. Pada aspek penulisan satuan, tidak terdapat miskonsepsi dalam buku ajar IP, VP, dan YW.
\end{abstract}

Kata Kunci: Miskonsepsi; Buku Ajar Fisika SMA; Dinamika Gerak

\section{Pendahuluan}

Buku ajar merupakan bagian yang tidak terpisahkan dari proses pembelajaran baik di sekolah maupun di perguruan tinggi. Buku ajar digunakan sebagai salah satu sumber belajar oleh guru/dosen dalam menyampaikan materi dan menentukan strategi pembelajarannya. Selain itu, siswa menggunakan buku ajar sebagai informasi untuk memahami materi (baik untuk mengerjakan tugas dan pekerjaan rumah). Buku ajar merupakan salah satu masukan (input) dalam proses pembelajaran yang ikut menentukan keberhasilan dan pencapaian tujuan intruksional, kurikuler, institusioanal, dan bahkan tujuan pendidikan nasional [1].

Ada berbagai macam buku ajar yang digunakan di sekolah dari berbagai pengarang dan penerbit, namun buku ajar tersebut belum tentu berkualitas. Banyak faktor-faktor yang dapat memengaruhi kualitas buku ajar, salah satunya adalah miskonsepsi. Miskonsepsi menunjukkan suatu konsep yang tidak sesuai dengan pengertian ilmiah atau pengertian yang diterima oleh pakar dalam suatu bidang [2]. Dengan keberadaan buku ajar tersebut, guru harus selektif dalam memilih buku ajar yang berkualitas. Buku ajar yang memuat miskonsepsi dapat menyebabkan terjadinya miskonsepsi pada siswa dalam proses pembelajaran. Miskonsepsi yang terjadi pada siswa akan menghambat penerimaan pengetahuan baru yangpada jenjang pendidikan yang lebih tinggi.

Miskonsepsi dapat terjadi terutama disebabkan oleh beberapa faktor, yaitu siswa, pengajar, buku teks, konteks, dan cara mengajar [2]. Suparno mengatakan bahwa beberapa miskonsepsi berasal dari buku ajar yang digunakan guru dan siswa [2]. Miskonsepsi dapat terjadi dalam bidang sains, seperti fisika, kimia, biologi, dan bumi antariksa. Pada bidang 


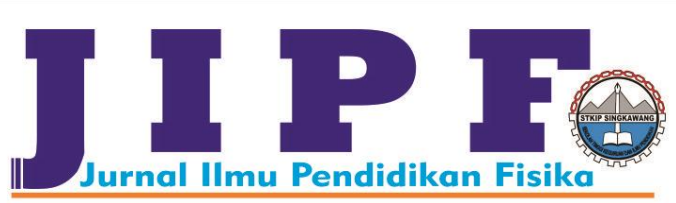

fisika, salah satu sub bidang yang banyak mengalami miskonsepsi adalah mekanika.

Penelitian tentang miskonsepsi pada bidang fisika cukup banyak dilakukan di Indonesia. Namun demikian, Suparno menyatakan bahwa penelitian tentang miskonsepsi yang terjadi dalam buku-buku teks sains (khususnya fisika) juga belum banyak dilakukan [2]. Penelitian yang berkaitan dengan buku ajar diantaranya yang berkaitan dengan analisis materi dari segi kedalaman konsep, miskonsepsi, comprehensible, tingkat keterbacaan, keluasan dan kesesuaian dengan kurikulum yang berlaku.

Berdasarkan latar belakang tersebut, maka akan dilakukan penelitian tentang miskonsepsi buku ajar fisika SMA kelas $\mathrm{X}$ pada pokok bahasan dinamika gerak khususnya materi hukum Newton tentang gerak. Tujuannya adalah untuk memaparkan bentuk-bentuk miskonsepsi pada pokok bahasan dinamika gerak dalam buku ajar fisika SMA kelas X.

\section{Metode PEnelitian}

Metode penelitian dalam penelitian ini adalah metode deskriptif sederhana. Jenis penelitian yang digunakan adalah analisis isi. Adapun tujuan analisis isi dalam penelitian ini untuk menyajikan fakta berupa miskonsepsi pada pokok dinamika gerak dalam buku ajar fisika SMA kelas X.

Populasi dalam penelitian ini adalah buku-buku ajar fisika SMA kelas $\mathrm{X}$ yang digunakan di beberapa sekolah di kota Singkawang. Sampel penelitian berupa buku-buku ajar fisika SMA yang dipilih secara acak dari populasi penelitian tersebut. Adapun buku ajar fisika SMA yang digunakan sebagai sampel penelitian, yaitu: (1) Fisika untuk SMA/MA Kelas X Semester I, karangan RA dan SI, penerbit IP, tahun terbit 2012, dan kurikulum KTSP, (2) Fisika untuk SMA/MA Kelas X Semester I, karangan TPM, penerbit VP, tahun terbit 2013, dan kurikulum 2013, dan (3) Fisika Peminatan Untuk SMA/MA Kelas X, karangan SN dan SZ, penerbit YW, tahun terbit 2013, dan kurikulum 2013. Data penelitian berupa aspek-aspek miskonsepsi pada buku ajar yang diteliti meliputi aspek penjelasan konsep, penulisan rumus, penulisan simbol, penulisan satuan, dan penyajian gambar.

Menurut Krippendorff, rangkaian desain analisis isi meliputi beberapa langkah berikut ini: (1) pembentukan data, (2) reduksi data, (3) penyajian data, (4) penarikan kesimpulan, dan (5) analisis data [3]. Dalam pembentukan data, peneliti terlebih dahulu merumuskan dengan tepat apa yang ingin diteliti dan semua tindakan harus didasarkan pada tujuan penelitian. Pembentukan data dapat diambil dalam bentuk unitisasi, sampling, dan pencatatan. Reduksi data berart merangkum, memilih hal-hal yang pokok, memfokuskan halhal yang penting, mencari tema dan polanya dan membuang yang tidak perlu. Dalam hal ini, data yang akan direduksi dalam buku ajar berhubungan dengan aspek-aspek miskonsepsi.

Pada tahap penyajian data, data-data dalam buku ajar yang telah dikumpulkan kemudian dibandingkan dengan data-data yang diambil pada buku acuan (buku teks fisika universitas). Data-data yang telah diperoleh dalam buku ajar kemudian dianalisis dengan melakukan studi pustaka. Konsep yang benar hasil studi pustaka diambil pada buku teks fisika universitas dan digunakan sebagai acuan dalam menganalisis miskonsepsi pada buku ajar. Penarikan kesimpulan diambil dengan memutuskan bahwa data dalam buku ajar mengalami miskonsepsi jika tidak sesuai dengan data pada buku acuan. Jika data dalam buku ajar sesuai dengan buku acuan, maka dianggap tidak mengalami miskonsepsi. Data-data dalam buku ajar yang mengalami miskonsepsi kemudian dianalisis dengan memberikan alasan penyebab data tersebut mengalami miskonsepsi dan juga memberikan saran agar data-data pada buku ajar tidak berpotensi mengalami miskonsepsi.

\section{HASIL DAN PEMBAHASAN}

Miskonsepsi pada buku ajar dapat dianalisis dengan melakukan studi pustaka. Konsep-konsep benar hasil studi pustaka digunakan sebagai acuan untuk menganalisis miskonsepsi pada buku ajar fisika SMA. Konsep-konsep tersebut diambil dari buku teks fisika universitas, yaitu: karangan Tipler, Giancoli, Serway \& Jewett, Halliday dkk, ITB, dan Young \& Freedman [4-8]. Dalam menganalisis suatu data, jika pada salah satu buku ajar data yang akan diteliti tidak ada, maka buku ajar tersebut dianggap tidak mengalami miskonsepsi pada data tersebut

Miskonsepsi pada aspek penjelasan konsep dalam buku ajar adalah kesalahan konsep-konsep dalam buku ajar berupa penjelasan yang kurang jelas, tidak tepat, terlalu matematis, pengggunaan bahasa yang kurang tepat maupun tidak sesuai dengan konsep-konsep yang ada pada buku acuan (buku teks fisika universitas). Adapun konsep-konsep yang diteliti antara lain konsep hukum I Newton, momen kelembaman, hukum II Newton, berat, hukum III Newton, gaya normal, gaya gesekan, gaya gesekan statis, gaya gesekan kinetis, dan gaya sentripetal.

Miskonsepsi pada aspek penulisan rumus adalah kesalahan penulisan rumus yang terdapat dalam buku ajar dan tidak sesuai dengan penulisan rumus pada buku acuan tanpa keterangan yang jelas. Adapun rumus yang diteliti antara lain rumus hukum I Newton, hukum II Newton, hukum III Newton, berat, besar gaya gesekan statis, besar gaya gesekan kinetis, dan besar gaya sentripetal.

Miskonsepsi pada aspek penulisan simbol adalah kesalahan penulisan simbol yang terdapat dalam buku ajar dan tidak sesuai dengan penulisan simbol pada buku acuan tanpa keterangan yang jelas. Adapun simbol yang diteliti antara lain resultan gaya, percepatan, massa, berat, percepatan gravitasi, gaya normal, gaya gesekan statis, gaya gesekan kinetis, koefesien gesekan statis, koefesien gesekan kinetis, tegangan tali, percepatan sentripetal, dan percepatan sentripetal.

Miskonsepsi pada aspek penulisan satuan adalah kesalahan penulisan satuan dalam buku ajar yang berbeda dengan penulisan satuan pada buku acuan tanpa keterangan yang jelas dan tidak sesuai dengan standar Sistem Internasional (SI) Adapun satuan yang diteliti antara lain resultan gaya, percepatan, massa, percepatan gravitasi, berat, gaya normal, gaya gesekan statis, gaya gesekan kinetis, gaya sentripetal, dan percepatan sentripetal.

Miskonsepsi pada aspek penyajian gambar adalah kesalahan penyajian gambar pada buku ajar, yaitu ketidaksesuian antara penjelasan konsep dengan penyajian gambar. Adapun gambar yang diteliti antara lain gaya normal, 


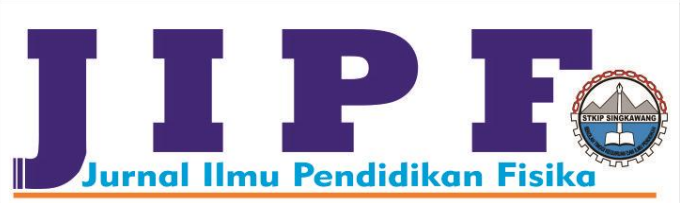

arah berat pada bidang miring, diagram gaya pada benda di atas bidang datar, diagram gaya pada kedua benda yang dihubungkan tali melalui katrol licin tidak bermassa, dan arah gaya sentripetal.

Analisis data dilakukan pada masing-masing aspek miskonsepsi dalam buku ajar fisika SMA yang meliputi aspek penjelasan konsep, penulisan rumus, penulisan simbol, penulisan satuan, dan penyajian gambar pada materi dinamika gerak. Hasil analisis berupa data-data dalam buku ajar yang mengalami miskonsepsi dan besarnya persentase miskonsepsi pada masing-masing aspek disajikan dalam Tabel 1 sebagai berikut.

TABEL 1

REKAPITULASI BENTUK-BENTUK MISKONSEPSI BUKU AJAR FISIKA SMA KELAS X PADA POKOK BAHASAN DINAMIKA GERAK

\begin{tabular}{cccc}
\hline \multirow{2}{*}{ Aspek yang diteliti } & \multicolumn{3}{c}{ Miskonsepsi Buku Ajar } \\
\cline { 2 - 4 } & IP & VP & YW \\
\hline Penjelasan konsep & $10 \%$ & $10 \%$ & $10 \%$ \\
Penulisan Rumus & $57,14 \%$ & $85,71 \%$ & $85,71 \%$ \\
Penulisan Simbol & $46,15 \%$ & $76,92 \%$ & $69,23 \%$ \\
Penulisan Satuan & $0 \%$ & $0 \%$ & $0 \%$ \\
Penyajian Gambar & $20 \%$ & $80 \%$ & $20 \%$ \\
\hline
\end{tabular}

Pada aspek penjelasan konsep dari ketiga buku ajar yang telah dianalisis, ada sedikit miskonsepsi yang terdapat dalam buku ajar tersebut. Masing-masing dari ketiga buku ajar hanya terdapat 1 penjelasan konsep yang miskonsepsi. Salah satu miskonsepsi yang teridentifikasi berupa penjelasan konsep mengenai hukum I Newton yang terdapat pada buku ajar VP. Miskonsepsi lainnya berupa penjelasan konsep mengenai gaya sentripetal pada buku ajar IP. Untuk buku ajar YW, miskonsepsi terdapat pada penjelasan konsep mengenai gaya gesekan statis.

Pada aspek penulisan rumus dari ketiga buku ajar, rumusrumus yang diteliti melalui analisis yang telah dilakukan, banyak mengalami miskonsepsi. Hanya ada beberapa penulisan rumus yang benar dari ketiga buku ajar tersebut. Buku ajar IP, penulisan rumus yang benar terdapat pada rumus gaya sentripetal. Sedangkan buku ajar VP, penulisan rumus yang benar terdapat pada rumus besar gaya gesekan kinetis. Untuk buku ajar YW, penulisan rumus yang benar terdapat pada rumus besar gaya gesekan statis.

Miskonsepsi pada aspek penulisan simbol juga banyak terdapat dalam buku ajar. Hanya ada beberapa penulisan simbol yang benar dari ketiga buku ajar tersebut. Buku ajar IP, penulisan simbol yang benar berupa simbol massa dan percepatan sentripetal. Sedangkan buku ajar VP, penulisan simbol yang benar berupa massa, koefesien gesekan statis dan koefesien gesekan kinetis. Untuk buku ajar YW, penulisan simbol yang benar berupa massa, gaya normal, koefesien gesekan statis, dan koefesien gesekan kinetis.

Pada aspek penulisan satuan dari ketiga buku ajar, tidak ada satupun miskonsepsi yang terjadi dalam ketiga buku ajar tersebut. Namun demikian, ada beberapa satuan yang tidak ada dalam buku ajar yang kemudian dianggap tidak mengalami miskonsepsi. Pada buku Ajar IP, satuan yang tidak ada berupa satuan gaya gesekan statis dan satuan gesekan kinetis. Sedangkan pada buku ajar VP, satuan yang tidak ada berupa satuan gaya sentripetal dan percepatan sentripetal.

Pada aspek penyajian gambar dari ketiga buku, ada beberapa miksonsepsi yang terdapat dalam buku ajar tersebut. Buku ajar VP, semua gambar yang disajikan mengalami miskonsepsi. Namun demikian, data berupa gambar arah gaya sentripetal tidak ada sehingga dianggap tidak mengalami miskonsepsi. Sedangkan buku ajar IP hanya mengalami miskonsepsi pada penyajian gambar berupa gaya normal. Untuk buku ajar YW terdapat satu miskonsepsi, yaitu gambar diagram gaya pada benda dalam bidang datar.

\section{KESIMPULAN}

Miskonsepsi aspek penjelasan konsep pada pokok bahasan dinamika gerak terdapat dalam buku ajar IP, VP, dan YW. Masing-masing buku ajar tersebut mengalami miskonsepsi dengan persentase $10 \%$. Pada aspek penjelasan penulisan, miskonsepsi pada pokok bahasan dinamika gerak juga terdapat dalam buku ajar IP, VP, dan YW. Buku ajar IP mengalami miskonsepsi pada aspek penulisan rumus dengan persentase $57,14 \%$ dan aspek penulisan simbol dengan persentase $46,15 \%$. Sedangkan buku ajar VP mengalami miskonsepsi pada aspek penulisan rumus dengan persentase $85,71 \%$ dan aspek penulisan simbol dengan persentase $76,92 \%$. Untuk buku ajar YW mengalami miskonsepsi pada aspek penulisan rumus dengan persentase $85,71 \%$ dan aspek penulisan simbol dengan persentase 69,23\%. Pada aspek penulisan satuan, tidak terdapat miskonsepsi dalam buku ajar IP, VP, dan YW. Pada aspek penyajian gambar, ada beberapa miskonsepsi pada materi dinamika gerak dalam buku ajar IP, VP, dan YW. Miskonsepsi pada aspek penyajian gambar terdapat dalam buku ajar VP dengan persentase $80 \%$. Sedangkan buku ajar IP dan YW mengalami miskonsepsi aspek penyajian gambar dengan persentase $20 \%$.

\section{UCAPAN TERIMAKASIH}

Penulis mengucapkan terima kasih kepada Drs. H. Andi Mursidi MPA., M.Si selaku ketua STKIP Singkawang yang telah memberikan dukungan materil dan moral kepada penulis. Tidak lupa juga penulis mengucapkan terima kasih kepada Andika Kusuma Wijaya, M.Pd.Si selaku penulis kedua dan Eka Murdani, S.Si., M.PFis selaku penulis ketiga yang banyak membantu dalam penyelesaian tulisan ini sehingga dapat dipublikasikan di berkala ilmiah STKIP Singkawang.

\section{DAFTAR PUSTAKA}

[1] Mukti, A.D.Y., Trustho Raharjo, \& Wiyono, E. (2012). Identifikasi Miskonsepsi dalam Buku Ajar Fisika SMA Kelas X Semester Gasal. Jurnal Materi dan Pembelajaran Fisika, 1(1).

[2] Suparno, P. (2005). Miskonsepsi dan Perubahan Konsep dalam Pendidikan Fisika. Yogyakarta: PT. Gramedia Widya Sarana.

[3] Krippendorff, K. (1991). Analisis Isi: Pengantar Teori dan Metodenya. Jakarta: Rajawali Press.

[4] Tipler, P. A. (1998). Fisika untuk Sains dan Teknik. Jakarta: Erlangga. 
[5] Giancoli, C.D. (2001). Fisika Edisi kelima (Terjemahan Yuhilza Hanum). Jakarta: Erlangga.

[6] Serway, R.A., \& Jewett, J.W. (2014). Fisika Untuk Sains dan Teknik Edisi 6 Buku 1. Jakarta: Salemba Teknika.

[7] Halliday, D., Resnick, R., \& Walker, J. (2001). DasarDasar Fisika Jilid I. Surabaya: Binarupa Aksara.

[8] ITB. (1998). Fisika Dasar 1, Mekanika dan Termodinamika Edisi 3. Bandung: ITB. 